\title{
Model Appreciative Learning untuk Perancangan Aktivitas dalam Serious Game Mitigasi Bencana
}

\author{
Hanny Haryanto ${ }^{1}$, Rahmatsyam Lakoro ${ }^{2}$, Umi Rosyidah ${ }^{3}$, Sendi Novianto ${ }^{4}$ dan Acun Kardianawati ${ }^{5}$ \\ ${ }^{1,3,4}$ Program Studi Teknik Informatika, Fakultas Ilmu Komputer, Universitas Dian Nuswantoro \\ ${ }^{1}$ hanny.haryanto@dsn.dinus.ac.id, ${ }^{3}$ umi.rosyidah@dsn.dinus.ac.id, ${ }^{4}$ sendi.novianto@dsn.dinus.ac.id \\ ${ }^{2}$ Departemen Desain Produk, Fakultas Desain Kreatif dan Bisnis Digital, Institut Teknologi Sepuluh \\ November \\ ${ }^{2}$ ramok@prodes.its.ac.id
}

${ }^{5}$ Program Studi Sistem Informasi, Fakultas Ilmu Komputer, Universitas Dian Nuswantoro 5 acun.kardianawati@dsn.dinus.ac.id

\begin{abstract}
Abstrak
Serious game merupakan sarana potensial untuk pelatihan mitigasi bencana karena memiliki kelebihan dalam memberikan pengalaman belajar yang menyenangkan sehingga materi dapat lebih mudah untuk dipahami. Permasalahan yang terjadi adalah perancangan aktivitas yang dilakukan dalam game belum terkonsep dengan baik. Dalam game edukasi, aktivitas inilah yang diisi oleh materi pembelajaran, oleh sebab itu perancangan aktivitas memerlukan konsep yang jelas. Appreciative Learning merupakan konsep pembelajaran yang didasarkan pada konsep Appreciative Inquiry, berfokus pada hal-hal positif seperti puncak pencapaian, peluang, eksplorasi potensi dan optimisme masa depan. Pembagian aktivitas berbasis Appreciative Learning dibagi menjadi empat tahap, yaitu : Discovery, Dream, Design, dan Destiny. Penelitian ini merancang aktivitas yang menggunakan konsep Appreciative Learning yang diterapkan pada serious game untuk pembelajaran mitigasi bencana dengan tujuan menghasilkan aktivitas dalam game yang lebih terkonsep. Hasil dari penelitian ini adalah serious game mitigasi bencana dengan aktivitas yang dirancang berdasarkan Appreciative Learning.
\end{abstract}

Kata kunci: aktivitas game, appreciative learning, mitigasi bencana, serious game.

\section{Appreciative Learning Model for Activity Design in Serious Game of Disaster Mitigation}

\begin{abstract}
Serious games are a potential tool for disaster mitigation training because they provide a pleasant learning experience to produce more understandable material. The problem that occurs is that the activities design carried out in the game is not well conceptualized. In educational games, this activity is filled with learning material, therefore designing activities requires a clear concept. Appreciative Learning is a learning concept based on Appreciative Inquiry, which focuses on positive things such as peak achievements, opportunities, exploration of potential and optimism for the future. Appreciative Learning is divided into four stages, namely: Discovery, Dream, Design, and Destiny. This study designed activities that use the concept of Appreciative Learning which is applied to the serious game for learning disaster mitigation with the aim of producing more conceptual in-game activities. The result of this research is a serious disaster mitigation game with activities designed based on Appreciative Learning.
\end{abstract}

Keywords: appreciative learning, disaster mitigation, game activity, serious game. 


\section{Pendahuluan}

Dilihat dari letak geografis, profil geologi, ekonomi dan kependudukan, Indonesia merupakan salah satu negara rawan bencana dengan potensi risiko bencana yang tinggi (Badan Nasional Penanggulangan Bencana, 2016). Secara umum kejadian bencana yang paling berpengaruh di Indonesia dibagi dua, yaitu bencana yang disebabkan oleh faktor geologis dan bencana yang disebabkan oleh hidrometeorologis (Badan Nasional Penanggulangan Bencana, 2018). Bencana geologi yang sering terjadi di Indonesia contohnya adalah tsunami, gempa bumi, gunung meletus dan tanah longsor, sedangkan jenis hidrometeorologi berupa banjir, gelombang dan cuaca ekstrim, kebakaran lahan dan kekeringan. Selain itu ada jenis bencana epidemi atau pandemi, namun yang paling sering terjadi di Indonesia dan menimbulkan kerugian yang cukup besar adalah bencana hidrometeorologi (Badan Nasional Penanggulangan Bencana, 2016). Kerugian materi dan korban jiwa dapat diminimalkan dengan adanya upaya mitigasi bencana (Badan Nasional Penanggulangan Bencana, 2012).

Dalam siklus tahapan manajemen bencana, mitigasi masuk ke dalam tahap prabencana, yang merupakan bagian dari persiapan menghadapi bencana (BPBD, 2018). Mitigasi terdiri dari tindakan-tindakan untuk meminimalkan dampak dari suatu bencana sebelum bencana tersebut terjadi, termasuk persiapan tempat perlidungan, alat-alat medis dan kebutuhan dasar seperti obat-obatan, peralatan survival dan makanan (Roskusumah, 2013). Berbagai upaya telah dilakukan untuk memperkenalkan mitigasi bencana sejak dini, antara lain yang dilakukan oleh (Pahleviannur, 2019) yang menekankan pentingnya peningkatan pemahaman terhadap siswa Sekolah Dasar melalui edukasi sadar bencana. Upaya membuat konten edukasi tentang mitigasi bencana yang lebih menyenangkan dan bisa diterima anak-anak juga dilakukan oleh (Anafiah \& Arief, 2018) dengan membuat buku cerita anak bertema penanggulangan bencana di Yogyakarta.

Serious game adalah permainan digital yang mempunyai tujuan lain di samping hiburan (Ghannem, 2014), tujuan tersebut antara lain adalah untuk edukasi. Serious game memiliki kelebihan dalam memberikan pengalaman belajar yang menyenangkan sehingga materi dapat lebih mudah untuk dipahami, terutama untuk edukasi anak usia dini (Papanastasiou et al., 2017). Oleh sebab itu, serious game menjadi salah satu sarana potensial untuk melakukan edukasi tentang mitigasi bencana. Dalam penggunaan serious 
game untuk edukasi, (Antoniou et al., 2013) dan (Mortara et al., 2014) menggunakannya untuk pelestarian budaya dan peninggalan sejarah. Di bidang yang lain, yaitu pembelajaran kewirausahaan, (La Guardia et al., 2014) meneliti tentang efektivitas serious game dalam menyampaikan materi yang didominasi unsur praktek dan menemukan bahwa game adalah sarana yang dapat menyampaikan materi yang memerlukan praktek atau pengalaman. Hal ini selaras dengan penelitian oleh (Yassine et al., 2017) yang menggunakan game untuk pembelajaran yang didominasi praktek, dalam hal ini adalah pembelajaran pemrograman. Hal tersebut menunjukkan bahwa serious game merupakan sarana potensial untuk pelatihan mitigasi bencana, dimana pelatihan mitigasi bencana merupakan pembelajaran yang harus dipraktekkan. (Chittaro \& Buttussi, 2015) dalam penelitiannya juga menemukan bahwa dengan menggunakan game, materi pembelajaran dapat lebih diingat oleh pembelajar dalam waktu yang lebih lama. Penggunaan serious game untuk pembelajaran mitigasi bencana juga sudah pernah dilakukan oleh (Kurniawan et al., 2017) yang membahas tentang edukasi tentang mitigasi bencana gempa bumi. Permasalahan yang terjadi selain jarangnya pemanfaatan serious game ini dalam edukasi mitigasi bencana, adalah juga perancangannya yang masih belum terkonsep dengan baik, terutama perancangan aktivitas yang dilakukan dalam game.

Aktivitas adalah elemen utama dari game, yang umumnya berbentuk quest atau misi (Carvalho et al., 2015). Dalam game edukasi, aktivitas inilah yang diisi oleh materi pembelajaran, oleh sebab itu perancangan aktivitas memerlukan konsep yang jelas. Salah satu konsep yang dapat digunakan untuk merancang aktivitas adalah Appreciative Learning (Leng et al., 2011). Appreciative Learning adalah konsep pembelajaran yang berangkat dari pencarian sesuatu yang positif dan mencapai sesuatu berdasarkan hal yang positif tersebut. Appreciative Learning merupakan konsep pembelajaran yang didasarkan pada konsep Appreciative Inquiry, berfokus pada hal-hal positif seperti puncak pencapaian, peluang, eksplorasi potensi dan optimisme masa depan (Eow et al., 2010). Pembagian aktivitas yang berbasis Appreciative Learning dibagi menjadi empat tahap, yaitu : Discovery, Dream, Design, dan Destiny (Eow et al., 2010).

Penelitian ini merancang aktivitas yang menggunakan konsep Appreciative Learning yang diterapkan pada serious game untuk pembelajaran mitigasi bencana dengan tujuan menghasilkan aktivitas dalam game yang lebih terkonsep sehingga 
nantinya dapat digunakan sebagai kerangka bagi game edukasi lain dan memudahkan evaluasi penerapan serious game.

\section{Metode}

Tahapan pada penelitian ini terdiri dari pengumpulan data dan identifikasi masalah, studi literatur, pembuatan konten materi mitigasi, pembuatan model Appreciative Learning untuk aktivitas, penerapan aktivitas pada serious game dan evaluasi aktivitas dalam serious game. Tahapan tersebut ditunjukkan pada Gambar 1 berikut.
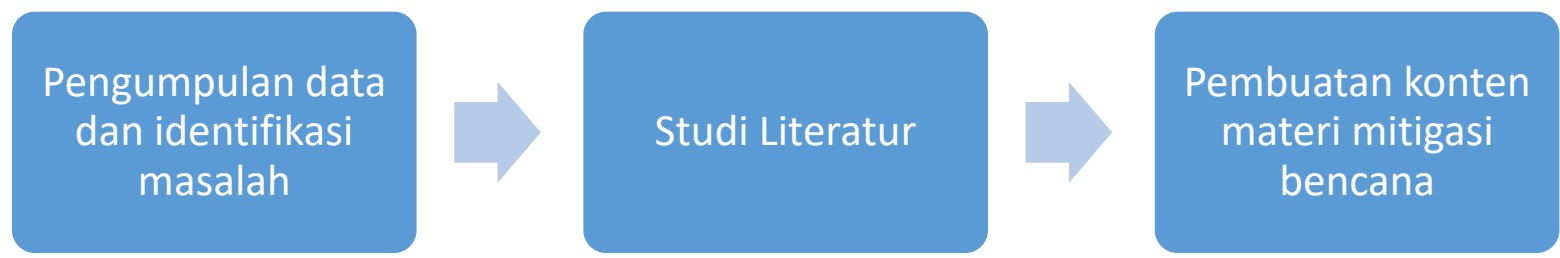

Evaluasi aktivitas

Gambar 1. Tahapan Penelitian.

Penjelasan dari tahapan penelitian di atas adalah sebagai berikut :

1. Pengumpulan data dan identifikasi masalah

Pada tahap ini dilakukan pengumpulan data tentang mitigasi bencana dan serious game.

Dari data-data yang terkumpul tersebut akan dilakukan identifikasi permasalahan.

2. Studi Literatur

Studi literatur dilakukan pada jurnal dan penelitian terkait tentang penggunaan serious game dan Appreciative Learning sebagai acuan kebaruan penelitian dan posisi penelitian 
ini dalam memberikan kontribusi terhadap bidang ilmu pengembangan game untuk edukasi.

3. Pembuatan konten materi pembelajaran mitigasi

Data materi mitigasi akan digunakan untuk membuat materi sebagai konten pedagogik game yang akan dibuat.

4. Pembuatan Model Appreciative Learning untuk Aktivitas dalam serious game Setelah konten terbentuk maka model Appreciative Learning akan diterapkan untuk merancang aktivitas dalam serious game.

5. Penerapan aktivitas pada serious game

Aktivitas untuk mitigasi bencana yang konsepnya sudah dirancang dengan model Appreciative Learning dan diterapkan ke dalam serious game.

6. Evaluasi aktivitas dalam serious game

Aktivitas mitigasi bencana yang ada di dalam serious game dievaluasi kesesuaiannya dengan model Appreciative Learning.

Pendekatan Appreciative Learning adalah pendekatan pembelajaran yang diungkapkan oleh (Eow et al., 2010) yang didasarkan pada konsep Appreciative Inquiry, yang mempunyai model yang ditunjukkan pada Gambar 2 sebagai berikut. 


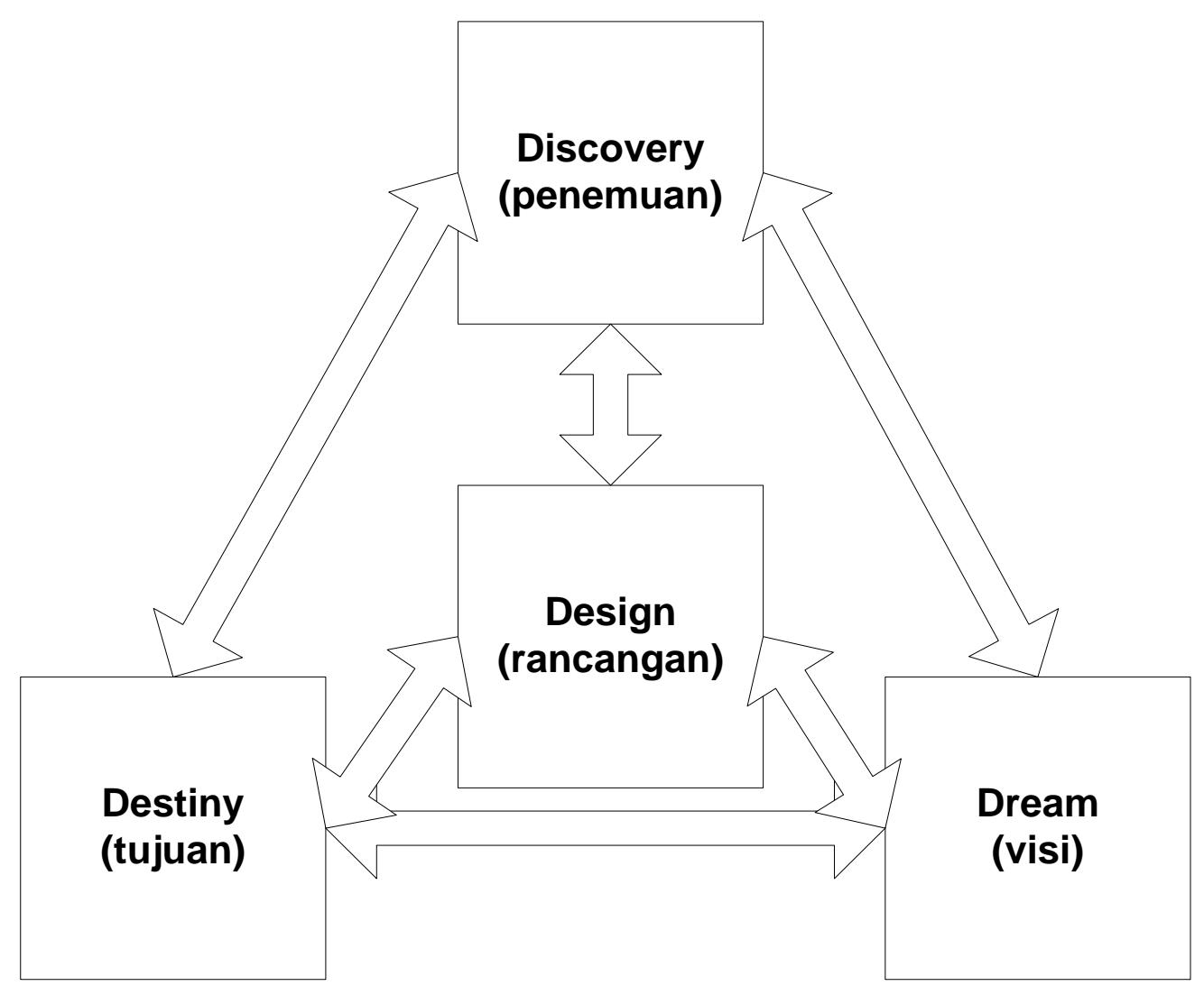

Gambar 2. Tahapan Appreciative Learning (Eow et al., 2010).

Tiap tahapan pada Gambar 2 berorientasi pada aktivitas. Tahap Discovery menemukan sesuatu yang positif atau yang merupakan kelebihan. Tahap Dream melihat sesuatu yang positif di masa depan. Tahap Design merancang sesuatu yang akan berjalan dengan baik dan positif di masa depan. Tahap Destiny mengimplementasikan tahap Design yang sudah dirumuskan. Appreciative Learning adalah konsep pembelajaran yang berangkat dari pencarian sesuatu yang positif dan mencapai sesuatu berdasarkan hal yang positif tersebut. Appreciative Learning merupakan konsep pembelajaran yang didasarkan pada konsep Appreciative Inquiry, berfokus pada hal-hal positif seperti puncak pencapaian, peluang, eksplorasi potensi dan optimisme masa depan (Eow et al., 2010). Pembagian aktivitas yang berbasis Appreciative Learning dibagi menjadi empat tahap, yaitu : Discovery, Dream, Design, dan Destiny (Eow et al., 2010).

\section{Hasil dan Pembahasan}

Kerangka pemikiran dari penelitian ini ditunjukkan pada Gambar 3 di bawah. 


\section{Permasalahan}

1. Kurangnya media pembelajaran dalam bentuk serious game yang dapat memberikan pengalaman praktis untuk mendukung pembelajaran tentang mitigasi bencana.

2. Aktivitas dalam serious game untuk edukasi /pembelajaran yang masih belum terkonsep dengan baik.

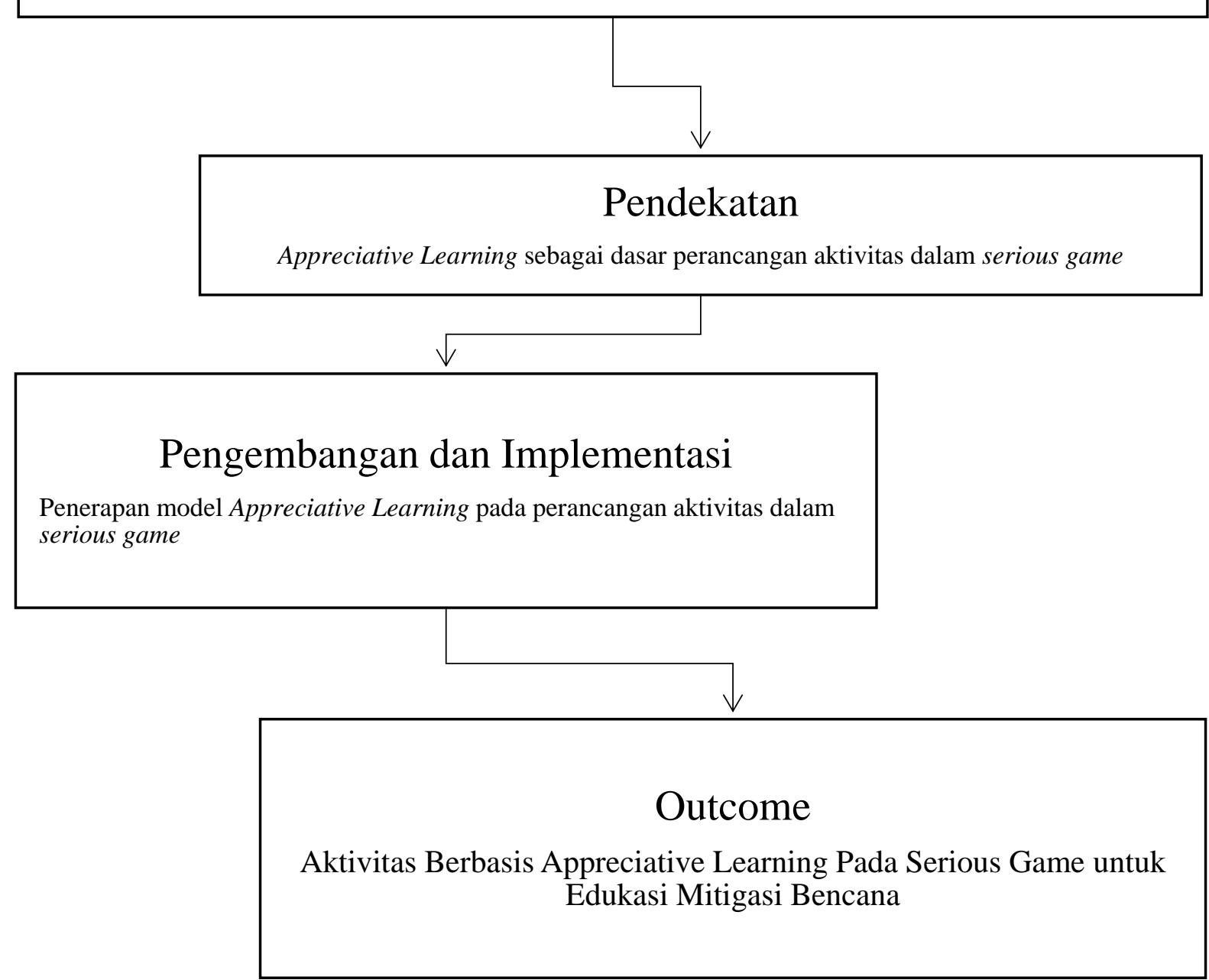

Gambar 3. Kerangka pemikiran dari penelitian. 


\section{Rancangan Game}

Gambaran dari game mitigasi bencana dapat dilihat dari Gambar 4 di bawah.

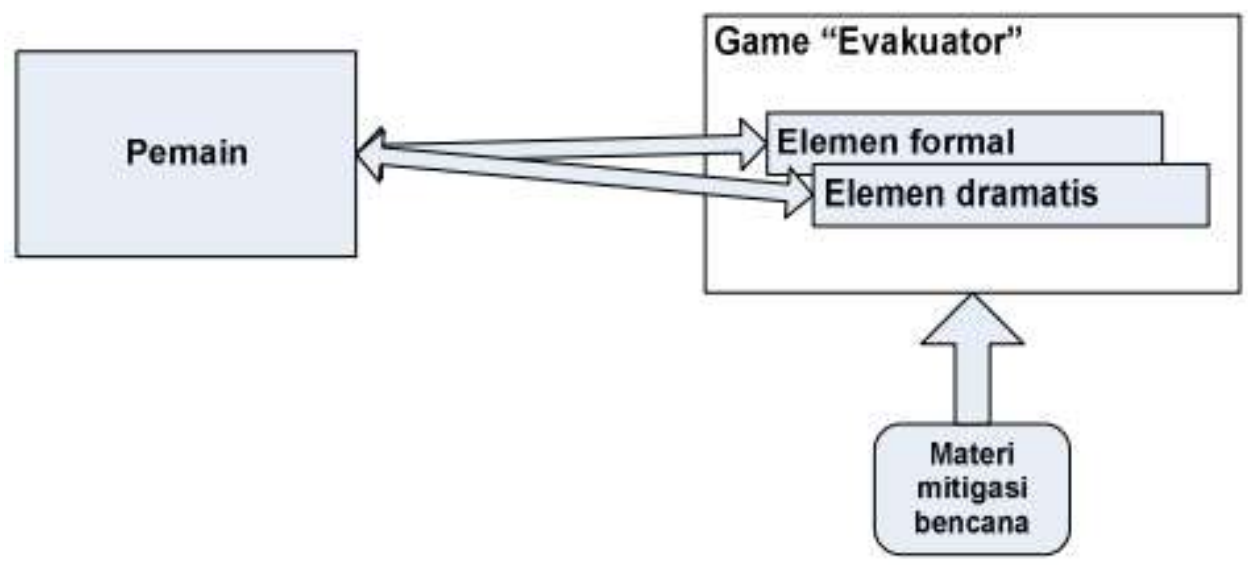

Gambar 4. Model Game.

Penelitian ini merancang aktivitas berbasis Appreciative Learning dalam game berjudul "Evakuator". Game puzzle "Evakuator" memiliki konsep permainan atau gameplay berupa mengklasifikasikan kebutuhan atau barang ke tempat / tas yang sesuai. Elemen formal dan dramatis adalah elemen pembentuk game, dimana elemen formal terdiri dari pemain, tujuan, prosedur, aturan, sumber daya, konflik, batasan dan hasil. Elemen ini merupakan elemen dasar dari sebuah game. Elemen dramatis adalah elemen tambahan yang membuat game jadi lebih menarik, yang terdiri dari tantangan, permainan, motif, karakter dan cerita (Fullerton et al., 2004). Materi mitigasi bencana didapatkan dari buku panduan resmi dari Badan Nasional Penanggulangan Bencana (BNPB, 2018).

Gambar 5 menunjukkan rancangan game setelah dimasukkan Appreciative Learning, Konten edukasi dan elemen game (formal dan dramatis) akan disusun menjadi aktivitas game. Perancangan aktivitas ini akan dirancang dengan menggunakan Appreciative Learning. Berdasarkan konsep Appreciative Learning maka jenis aktivitas dalam game dibagi empat, yaitu : aktivitas discovery, dream, desain, dan destiny. 


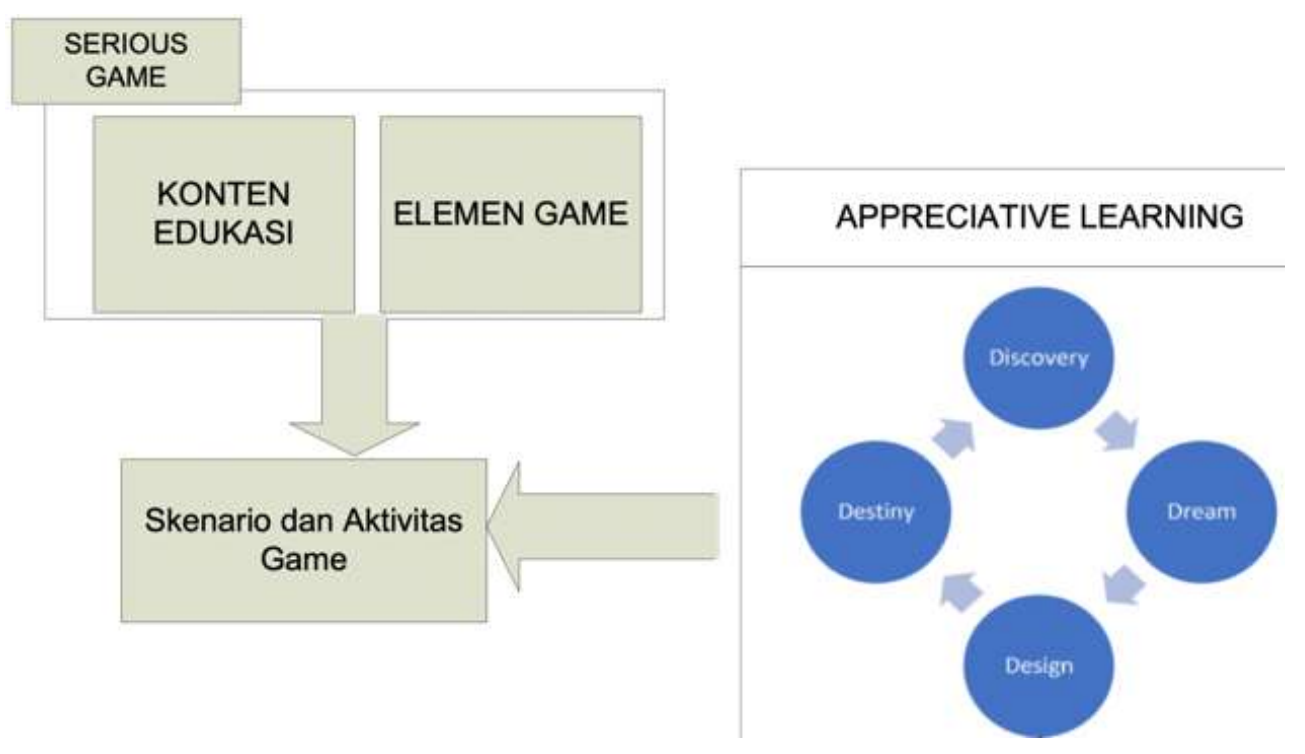

Gambar 5. Model Game dengan Appreciative Learning

\section{Materi Mitigasi Bencana}

Mitigasi bencana merupakan usaha untuk mengurangi risiko dari dampak suatu bencana sebelum bencana tersebut terjadi (BNPB, 2018). Usaha ini dapat berupa persiapan bangunan sebagai tempat perlindungan, persiapan alat-alat medis dan kebutuhan dasar seperti obat-obatan, peralatan survival dan makanan (Roskusumah, 2013). Pengarahan yang ditujukan untuk kesadaran masyarakat dan peningkatan kewaspadaan dan kemampuan masyarakat juga merupakan bagian dari mitigasi bencana.

Berdasarkan waktunya, tindakan atau aktivitas penanganan bencana terdiri dari empat kategori sebagai berikut :

- Mitigasi (sebelum bencana terjadi)

- Perlindungan dan evakuasi (saat bencana terjadi)

- Pencarian dan penyelamatan (tepat setelah bencana terjadi)

- Pemulihan/penyembuhan dan perbaikan/rehabilitasi (setelah bencana terjadi)

Dalam siklus tahapan manajemen bencana, mitigasi masuk ke dalam tahap prabencana, yang merupakan bagian dari persiapan menghadapi bencana dengan tujuan sebagai berikut (BPBD, 2018) :

- Meminimalkan dampak bencana bagi penduduk 
- Sebagai dasar dalam perencanaan pembangunan di daerah rawan bencana

- Meningkatkan kesadaran, pengetahuan, dan kemampuan masyarakat dalam menghadapi dan mempersiapkan potensi terjadinya bencana.

Beberapa contoh aktivitas mitigasi bencana diantaranya adalah sebagai berikut :

- pengenalan dan pemantauan risiko bencana

- pengembangan kesadaran siap bencana

- perencanaan partisipatif dan penerapan upaya fisik, nonfisik, serta pengaturan penanggulangan bencana

- identifikasi dan pengenalan terhadap sumber bahaya atau ancaman bencana

- pemantauan terhadap pengelolaan sumber daya alam dan teknologi

- pengawasan terhadap tata ruang dan pengelolaan lingkungan hidup

Salah satu hal yang sangat penting dalam materi mitigasi bencana adalah wawasan mengenai barang-barang pendukung atau disebut survival kit, seperti makanan dan obatobatan. Jenis barang-barang tersebut adalah obat-obatan, peralatan pelindung, peralatan komunikasi dan makanan, Objek penelitian ini terutama berfokus pada usaha untuk meningkatkan kesadaran dan wawasan masyarakat tentang barang pendukung / survival kit dalam menghadapi dan mempersiapkan potensi terjadinya bencana.

\section{Gameplay}

Game "Evakuator" memiliki konten pembelajaran berupa pengenalan barangbarang pendukung / survival kit dalam mitigasi bencana. Game "Evakuator" adalah game bergenre puzzle matching object dimana fokus utamanya adalah memilih barang yang cocok dengan tasnya. Dengan gameplay semacam ini, pemain akan belajar mengamati dan memilih barang yang tepat secara berulang-ulang sehingga diharapkan materi dapat tersampaikan. Barang-barang tersebut dibagi menjadi empat, yaitu obat-obatan, peralatan pelindung, komunikasi dan makanan, seperti ditunjukkan pada Gambar 6 berikut. 


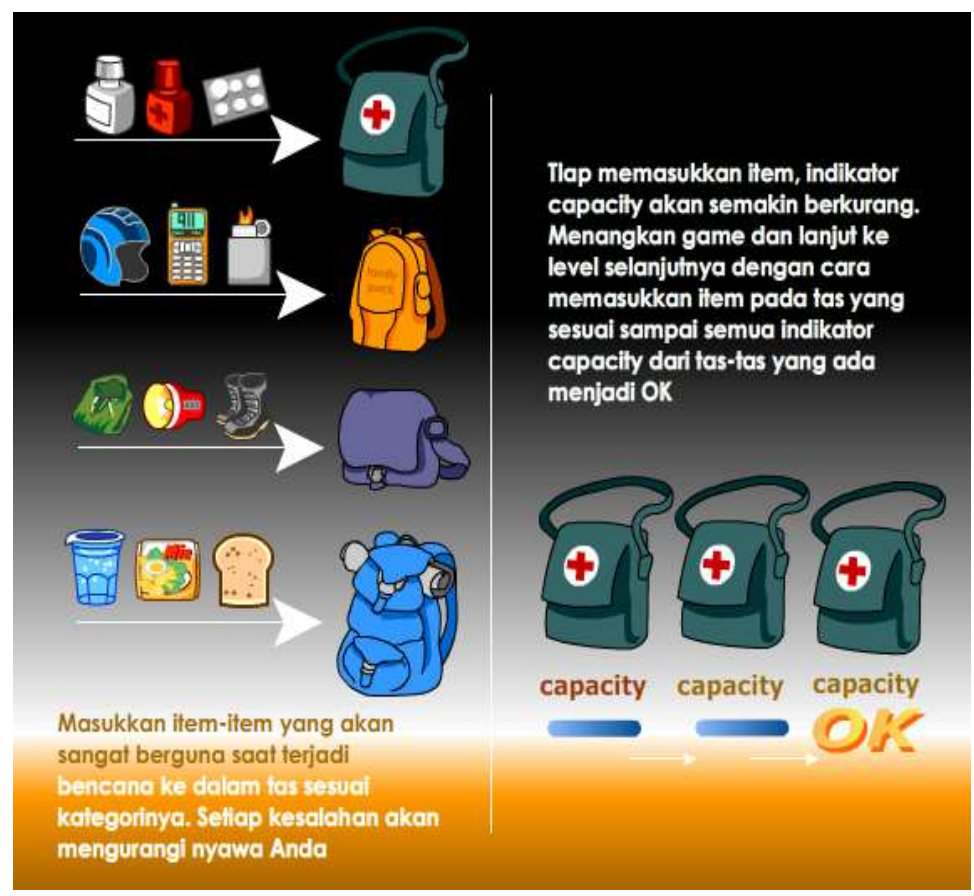

Gambar 6. Jenis Barang

Gameplay dari Evakuator adalah pemain harus memilih dan memasukkan barang ke tas yang sesuai jenisnya seperti ditunjukkan pada Gambar 7 berikut. Kontrol game menggunakan mouse, klik dan drag. Tujuan permainan adalah memenuhi tas-tas yang ada dengan barang-barang tersebut sampai kapasitasnya penuh. Barang-barang tersebut diklasifikasikan ke empat tas yang tersedia. Kesalahan memasukkan akan berakibat pada berkurangnya life yang ditunjukkan di bagian kiri atas tampilan game, dan jika life habis maka permainan akan berakhir. Waktu dimulai dari 99 dan terus akan berkurang. Jika waktu habis namun barang-barang belum selesai dimasukkan dalam tas maka permainan akan berakhir. Memasukkan barang yang tepat dengan tas akan menambah score pemain. Permainan berlanjut ke level selanjutnya jika semua tas telah diisi penuh. 


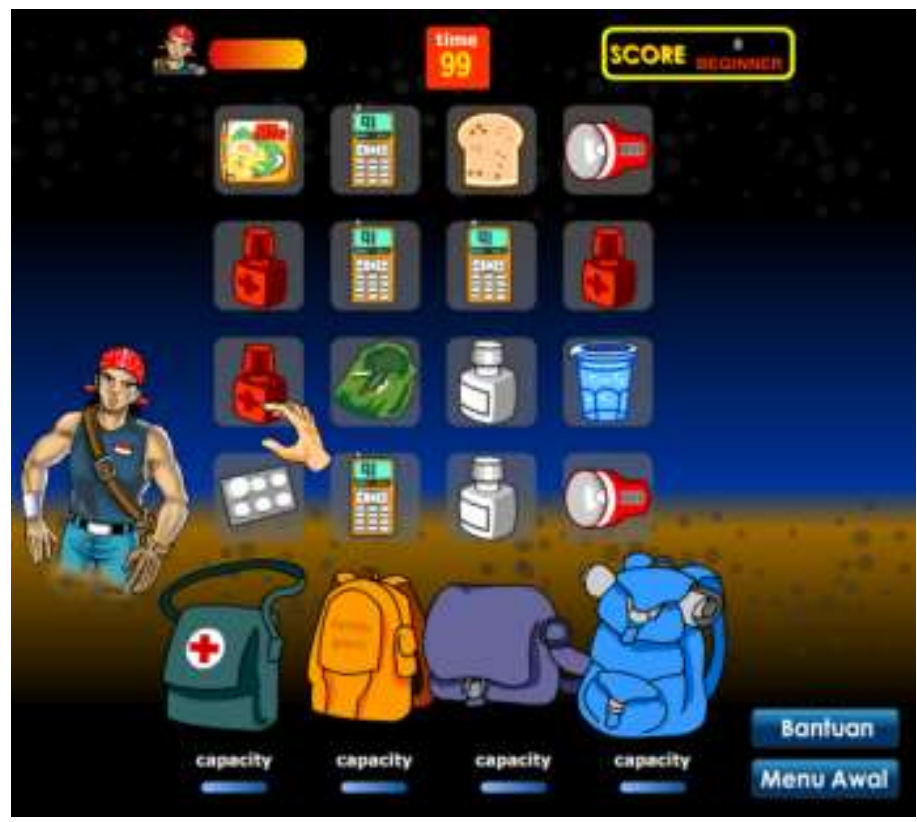

Gambar 7. Gameplay Evakuator

\section{Aktivitas Berbasis Appreciative Learning}

Aktivitas game akan disusun berdasarkan tahapan Appreciative Learning seperti yang ditunjukkan pada Tabel 1 berikut.

Tabel 1. Pengelompokan aktivitas pada tahapan Appreciative Learning.

\begin{tabular}{|l|c|}
\hline $\begin{array}{c}\text { Tahapan } \\
\text { Appreciative } \\
\text { Learning }\end{array}$ & $\begin{array}{c}\text { Aktivitas dalam } \\
\text { Game }\end{array}$ \\
\hline Discovery & $\begin{array}{c}\text { Pemain melihat tampilan } \\
\text { semua item survival kit } \\
\text { yang tersedia dan tasnya }\end{array}$ \\
\hline Dream & $\begin{array}{c}\text { Pemain mulai mempelajari } \\
\text { barang mana yang tepat } \\
\text { dimasukkan ke dalam tas }\end{array}$ \\
\hline Design & $\begin{array}{c}\text { Pemain memasukkan item } \\
\text { yang tepat ke dalam tas } \\
\text { yang sesuai }\end{array}$ \\
\hline Destiny & $\begin{array}{c}\text { Pemain mendapatkan } \\
\text { reward berupa skor, status } \\
\text { dan reaksi karakter yang } \\
\text { mendukung }\end{array}$ \\
\hline
\end{tabular}


Gambar 8 menunjukkan tahapan Discovery, dimana game akan menampilkan pilihan barang yang tersedia sehingga pemain dapat melihat barang-barang tersebut adalah barang yang mendukung untuk bertahan hidup ketika terjadi bencana.

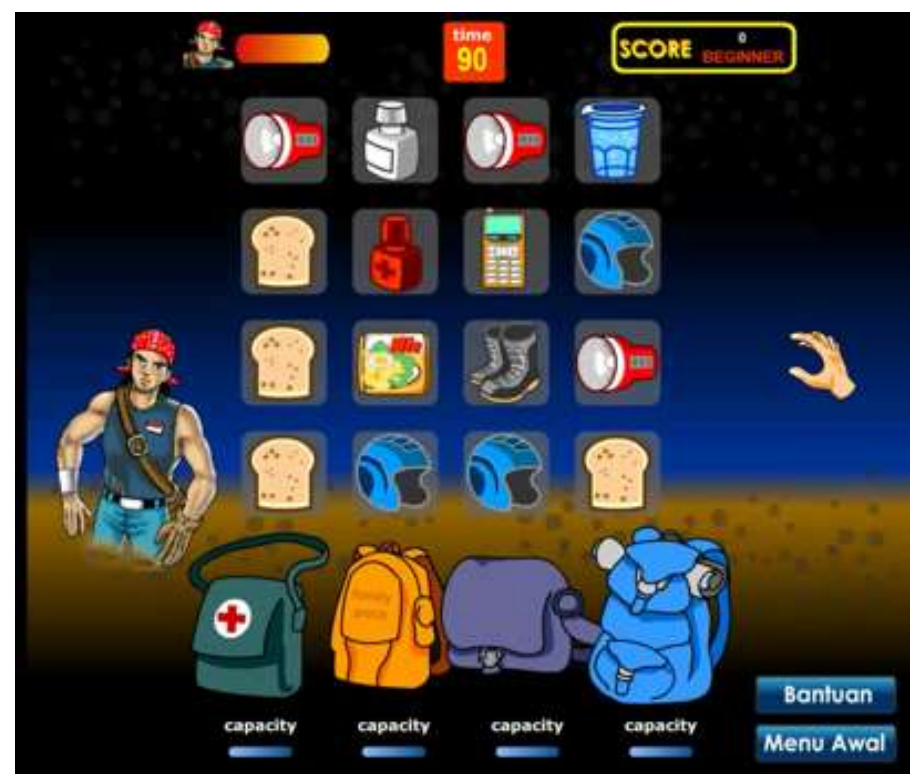

Gambar 8. Tampilan item yang dapat dipilih

Tahapan Dream ditunjukkan pada Gambar 9, dimana pemain mulai mempelajari barang mana yang tepat untuk dimasukkan dalam tas yang sesuai. Disini pemain dapat mengakses menu Bantuan pada saat bermain.

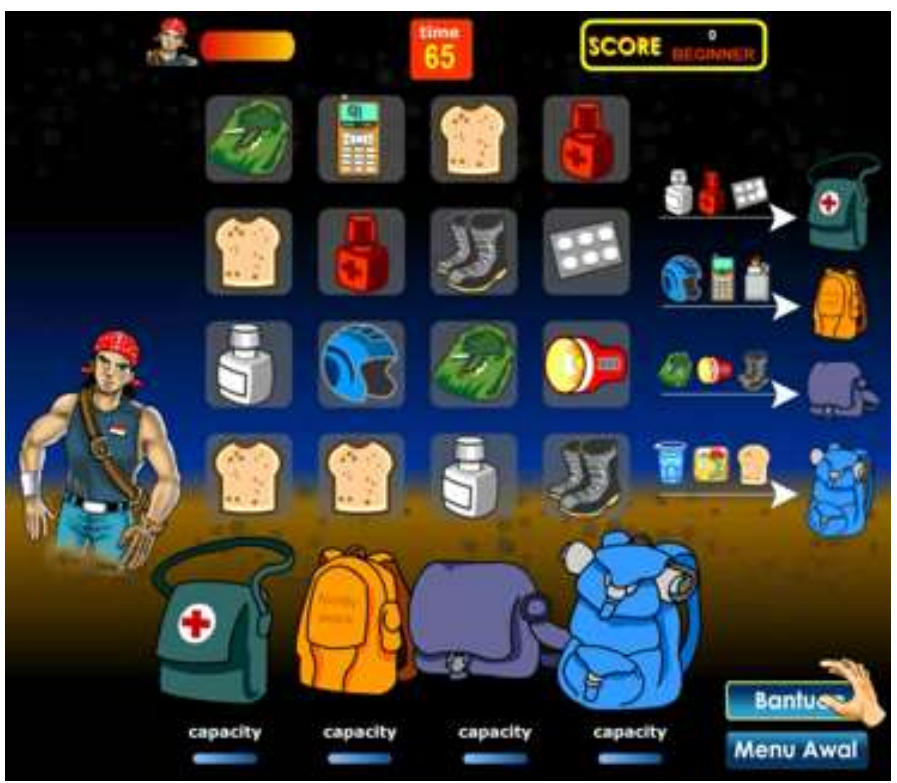

Gambar 9. Pemain dapat mempelajari barang yang tepat pada menu Bantuan 
Tahapan Design adalah aktivitas dimana pemain mulai memasukkan item yang tepat ke dalam tas yang sesuai. Hal ini ditunjukkan pada Gambar 10 berikut.

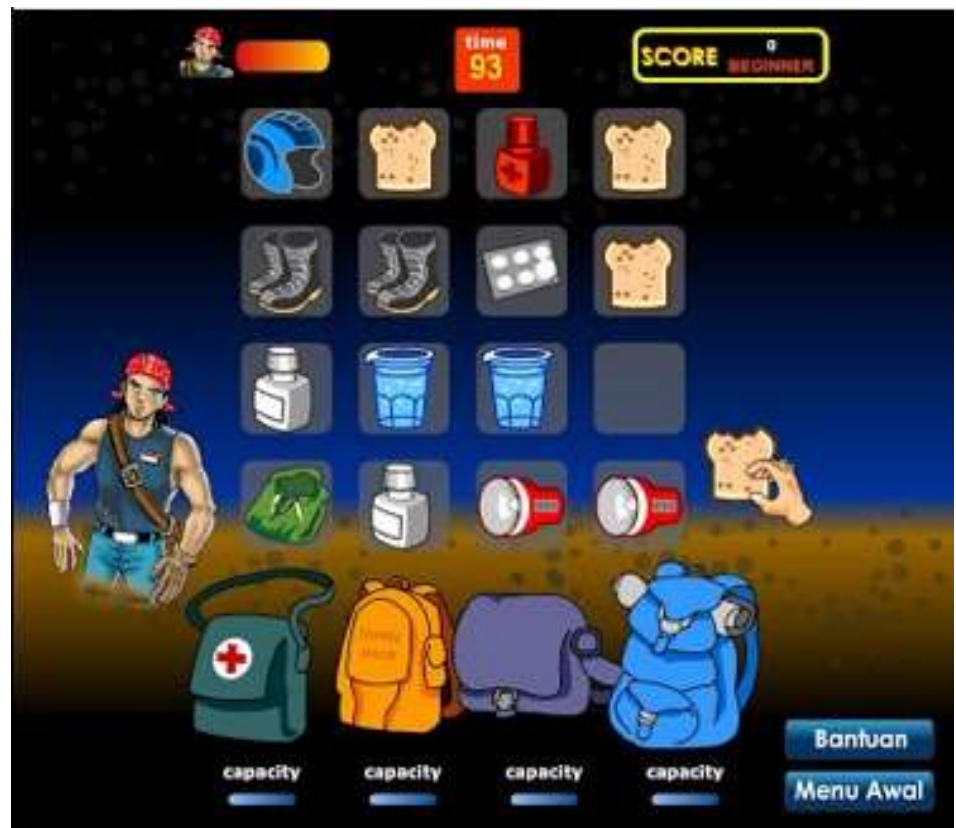

Gambar 10. Pemain mulai memasukkan barang ke tas yang sesuai

Kemudian tahapan Destiny, dimana pemain mendapatkan reward berupa skor dan status yang ditampilkan di bagian kanan atas, dan juga reaksi karakter utama yang mendukung jika barang yang dimasukkan tepat. Gambar 11 menunjukkan reaksi karakter ketika pemain tepat memasukkan barang, dan Gambar 12 adalah skor dan status yang didapatkan.

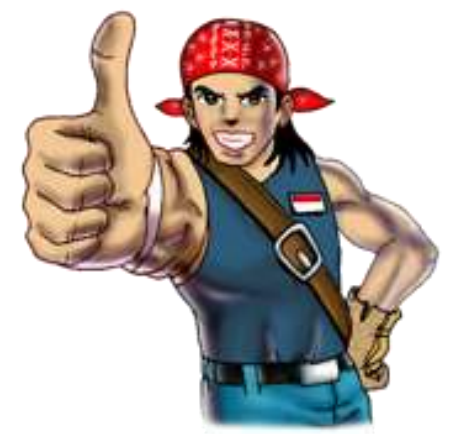

Gambar 11. Reaksi karakter ketika pemain memasukkan barang yang tepat

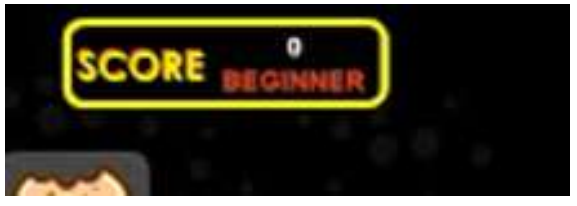

Gambar 12. Bagian tampilan skor dan status 


\section{Kesimpulan}

Penelitian ini telah menerapkan konsep Appreciative Learning untuk membuat aktivitas game, dimana aktivitas dalam game menjadi lebih terkonsep dengan baik dengan prinsip yang jelas. Penelitian ke depan akan menerapkan Appreciative Learning ke aktivitas yang lebih kompleks dan melakukan pengujian terhadap respon pengguna terhadap aktivitas yang dirancang.

\section{Ucapan Terima Kasih}

Ucapan terimakasih diberikan kepada LPPM Universitas Dian Nuswantoro Semarang yang telah mendanai penelitian ini melalui program hibah Penelitian Terapan Perguruan Tinggi.

\section{Referensi}

Anafiah, S., \& Arief, A. (2018). PEMBUATAN BUKU CERITA ANAK BERMUATAN PENANGGULANGAN BENCANA DI SDN BANGUNREJO 1, SDN BANGUNREJO 2, DAN SDN BALUWARTI YOGYAKARTA. Abdi, 3(2), 88-92. https://journal.unesa.ac.id/index.php/abdi/article/view/2383

Antoniou, A., Lepouras, G., Bampatzia, S., \& Almpanoudi, H. (2013). An Approach for Serious Game Development for Cultural Heritage: Case Study for an Archaeological Site and Museum. ACM Journal on Computing and Cultural Heritage, 6(4), 17.1-17.19. https://doi.org/10.1145/2532630.2532633

Badan Nasional Penanggulangan Bencana. (2012). Buku Saku Tanggap Tangkas Tangguh Menghadapi Bencana. In Badan Nasional Penanggulangan Bencana. https://doi.org/10.1016/j.jpcs.2003.10.007

Badan Nasional Penanggulangan Bencana. (2016). Risiko Bencana Indonesia (Disasters Risk of Indonesia). In Risiko Bencana Indonesia. BNPB.

Badan Nasional Penanggulangan Bencana. (2018). IRBI (Indeks Risiko Bencana Indonesia).

BNPB. (2018). Buku Panduan Hari Kesiapsiagaan Bencana. BNPB.

BPBD. (2018). Pengertian Mitigasi Bencana. BPBD Karanganyar. http://bpbd.karanganyarkab.go.id/?p=603

Carvalho, M. B., Bellotti, F., Berta, R., De Gloria, A., Sedano, C. I., Hauge, J. B., Hu, J., \& Rauterberg, M. (2015). An activity theory-based model for serious games analysis and conceptual design. Computers and Education, 87, 166-181. https://doi.org/10.1016/j.compedu.2015.03.023

Chittaro, L., \& Buttussi, F. (2015). Assessing knowledge retention of an immersive serious game vs. A traditional education method in aviation safety. IEEE Transactions on Visualization and Computer Graphics, 21(4), 529-538. https://doi.org/10.1109/TVCG.2015.2391853

Eow, Y. L., Zah, W. A. W., Rosnaini, M., \& Roselan, B. (2010). Appreciative Learning Approach: A New Pedagogical Option. Proceedings of the 18th International Conference on Computers in Education, 607-614. 
Fullerton, T., Swain, C., \& Hoffman, S. (2004). Game Design Workshop: Designing, Prototyping, and Playtesting Games. CMP Books. https://doi.org/10.1002/9780470114735.hawley03921

Ghannem, A. (2014). Characterization of Serious Games Guided by the Educational Objectives. Proceedings of the Second International Conference on Technological Ecosystems for Enhancing Multiculturality. https://doi.org/http://dx.doi.org/10.1145/2669711.2669904

Kurniawan, R., Mahtarami, A., \& Rakhmawati, R. (2017). GEMPA : Game Edukasi sebagai Media Sosialisasi Mitigasi Bencana Gempa Bumi bagi Anak Autis. Jurnal Nasional Teknik Elektro Dan Teknologi Informasi (JNTETI), 6(2), 174-183. https://doi.org/10.22146/JNTETI.V6I2.312

La Guardia, D., Gentile, M., Dal Grande, V., Ottaviano, S., \& Allegra, M. (2014). A Game based Learning Model for Entrepreneurship Education. Procedia - Social and Behavioral Sciences, 141, 195-199. https://doi.org/10.1016/j.sbspro.2014.05.034

Leng, E. Y., Wan Zah, W. A., Mahmud, R., \& Roselan, B. (2011). Appreciative Learning Approach as a Pedagogical Strategy and Computer Game Development as a Technological Tool in Enhancing Students' Creativity. Journal of the Research Center for Educational Technology, 7(2), 60-85.

Mortara, M., Catalano, C. E., Bellotti, F., Fiucci, G., Houry-Panchetti, M., \& Petridis, P. (2014). Learning cultural heritage by serious games. In Journal of Cultural Heritage (Vol. 15, Issue 3). https://doi.org/10.1016/j.culher.2013.04.004

Pahleviannur, M. R. (2019). Edukasi Sadar Bencana Melalui Sosialisasi Kebencanaan Sebagai Upaya Peningkatan Pengetahuan Siswa Terhadap Mitigasi Bencana. Jurnal Pendidikan Ilmu Sosial, 29(1), 49-55. https://doi.org/10.23917/jpis.v29i1.8203

Papanastasiou, G. P., Drigas, A. S., \& Skianis, C. (2017). Serious Games in Preschool and Primary Education: Benefits And Impacts on Curriculum Course Syllabus Serious Games in Preschool and Primary Education: Benefits And Impacts on Curriculum Course Syllabus. International Journal of Emerging Technologies in Learning (IJET), 12(1), 44-57. https://doi.org/10.3991/ijet.v12i01.6065

Roskusumah, T. (2013). Komunikasi Mitigasi Bencana oleh Badan Geologi KESDM di Gunung Api Merapi Prov. D. I. Yogyakarta. Jurnal Kajian Komunikasi, 1(1), 59. https://doi.org/10.24198/jkk.v1i1.6031

Rosyid, H. A., Palmerlee, M., \& Chen, K. (2018). Deploying learning materials to game content for serious education game development: A case study. Entertainment Computing, 26(May 2018), 1-9. https://doi.org/10.1016/j.entcom.2018.01.001

Wouters, P., van Nimwegen, C., van Oostendorp, H., \& van Der Spek, E. D. (2013). A meta-analysis of the cognitive and motivational effects of serious games. Journal of Educational Psychology. https://doi.org/10.1037/a0031311

Yassine, A., Chenouni, D., Berrada, M., \& Tahiri, A. (2017). A Serious Game for Learning $\mathrm{C}$ Programming Language Concepts Using Solo Taxonomy. International Journal of Emerging Technologies in Learning (IJET), 12(03), 110-127. https://doi.org/10.3991/ijet.v12i03.6476 